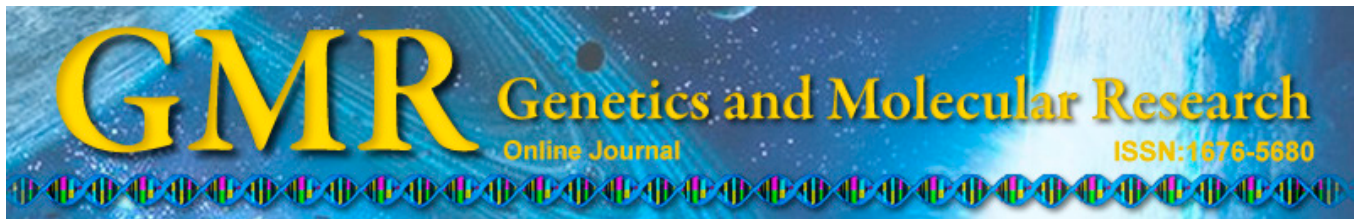

\title{
Association between $C$ YP1A1m1 gene polymorphism and primary open-angle glaucoma
}

\author{
N.B. Costa, C.T.X. Silva, A.B. Frare, R.E. Silva and \\ K.K.V.O. Moura \\ Pontifícia Universidade Católica de Goiás, Goiânia, GO, Brasil \\ Corresponding author: N.B. Costa \\ E-mail: nath_bc3@hotmail.com
}

Genet. Mol. Res. 13 (4): 10382-10389 (2014)

Received April 2, 2014

Accepted August 8, 2014

Published December 4, 2014

DOI http://dx.doi.org/10.4238/2014.December.4.33

\begin{abstract}
The CYP1A1 gene is related to the generation of secondary metabolites that are capable of inducing DNA damage. The CYP1A1m1 polymorphism has been examined in many studies, and is located in a region near loci that have been linked to glaucoma, including the locus GLC1I. As a result, this polymorphism has been related to several diseases that are influenced by exposure to xenobiotic as well as primary open-angle glaucoma. We compared the prevalence of the CYP $1 A 1 \mathrm{~m} 1$ polymorphism in 152 Brazilian patients, 100 patients with primary open-angle glaucoma, and 52 normal controls using restriction fragment length polymorphism analysis. The frequency of the homozygous wild-type (w1/w1) CYP1A1 gene among patients with primary open-angle glaucoma $(\mathrm{N}=100)$ was $16 \%$, for genotype $\mathrm{w} 1 / \mathrm{m} 1$, the frequency was $77 \%$, and for $\mathrm{m} 1 / \mathrm{ml}$ it was $7 \%$. Among the control group $(\mathrm{N}=52)$, the frequency of the homozygous wild-type (w1/w1) CYP1A1 gene was $54 \%$, the frequency of w1/m1 was $46 \%$, and the frequency of $\mathrm{m} 1 / \mathrm{m} 1$ was $0 \%$. The presence of the CYP 1 A $1 \mathrm{~m} 1$ polymorphism may interfere with xenobiotic metabolism and exacerbate direct or indirect damage to the optic nerve. These CYP1Alm1
\end{abstract}


polymorphisms may be risk factors for primary open-angle glaucoma.

Key words: CYP1A1; CYP1A1m1; Glaucoma; Polymorphism; Primary open-angle glaucoma; Restriction fragment length polymorphism

\section{INTRODUCTION}

Glaucoma is a complex and genetically heterogeneous optic neuropathy that includes a number of eye diseases characterized by progressive death of retinal ganglion cells through apoptosis. The process is responsible for progressive damage to the optic nerve and loss of vision (Quigley et al., 1995). Glaucoma can be divided into 4 main groups: 1) primary openangle glaucoma (POAG), which has the highest incidence rate; 2) angle-closure glaucoma; 3) combined glaucoma; and 4) congenital glaucoma (Stamper et al., 1999). According to the age at onset of glaucoma, POAG can be classified into juvenile primary open-angle glaucoma and adult-onset primary open-angle glaucoma (Johnson et al., 1996).

Intraocular pressure is an important risk factor for POAG (Stewart et al., 2000). It is more prevalent, more serious, and shows the worst prognosis in the black ethnic group (Tielsch et al., 1994). Heredity, cardiovascular diseases, exfoliation syndrome, and pigment dispersion syndrome are also considered risk factors for POAG (Stewart et al., 2000). Both the incidence and prevalence of the disease increase with age (Quigley and Vitale, 1997). Four genes have been found to be associated with POAG in the 22 loci reported. These genes include $M Y O C / T I G R, O P T N$, and WDR36 related to adult-onset primary open-angle glaucoma, and CYP1B1 related to juvenile primary open-angle glaucoma (Stone et al., 1997; Stoilov et al., 1997; Rezaie et al., 2002; Monemi et al., 2005).

The gene MYOC (1q24.3-q25.2, the GLC1A locus) was the first glaucoma-related gene to be identified (Stone et al., 1997). The OPTN gene was identified in chromosome 10p14-p15, and causes normal-pressure glaucoma, which is a subtype of POAG (Stoilov et al., 1997). A new locus related to POAG $(G L C l G)$ and the gene that causes the disease, WDR36 in chromosome 5q21.3-q22.1, were identified by Monemi et al. (2005). Mutations in $C Y P 1 B 1$ (2p22-p21, the GLC3A locus) are likely to cause juvenile primary open-angle glaucoma or risk factors for the disease (Rezaie et al., 2002). Silva et al. (2009) found no association between the codon 72 polymorphism in the Tp53 gene and POAG, but some studies have identified differences (Lin et al., 2002). In 2012, Silva (unpublished data) noted a statistically significant relationship between POAG and the GSTM1 null polymorphism, but no significant relationship was found between these factors. Barbosa et al. (2012) found no statistically significant relationship between POAG and GSTM1.

Each day, humans are exposed to numerous compounds that are foreign to the body, known as xenobiotics; their elimination from the body depends on a process referred to as biotransformation (Franco and Franco, 2003). The xenobiotic-metabolizing machinery is formed by phase I and phase II enzymes. Many external compounds are converted into highly reactive metabolites by phase I oxidative enzymes, particularly the cytochrome p450 gene superfamily (CYP). Phase II reactions are established by conjugation with an endogenous substrate through glutathione S-transferase, UDP glucuronyl transferase, and $\mathrm{N}$-acetyltransferase, which inactivate products of phase I by converting them into hydrophilic metabolites that are easily excreted from the body (Rossit and Conforti-Froes, 2000). 
CYP1A1 is among the most important genes in the CYP1 family and is related to the generation of secondary metabolites, which are capable of inducing DNA damage. The CYP1A1 gene is located on chromosome 15q22-q24 and is composed of 7 exons (Corchero et al., 2001). Two different polymorphisms have been identified to be associated with CYPIA1. First, the $\mathrm{m} 1$ polymorphism $(C Y P 1 A 1 \mathrm{~m} 1)$ or $C Y P 1 A 1 * 2 \mathrm{~A}$ is characterized by a $\mathrm{T}$ to $\mathrm{C}$ transition in exon 7 in the 3 ' non-coding region, where it eventually establishes a cleavage site (Msp I restriction enzyme site). Second, the $\mathrm{m} 2$ polymorphism, characterized by an A to $\mathrm{G}$ transition, leads to an amino acid substitution from valine to isoleucine at codon 462 (Slattery et al., 2004).

Locus GLC1I has been linked to glaucoma and is located on chromosome 15q11-13. This region is close to the polymorphism CYP1A1m1 (15q22-24), which has been widely examined and related to several diseases that are influenced by exposure to xenobiotics as well as POAG (Mahdy, 2010).

The identification of new modifier genes that may contribute either to the onset of disease or to decreasing disease severity is very important. These studies increase the understanding of the mechanisms by which glaucoma develops, enable better treatment, and improve diagnostic methods. This is important for avoiding a larger socioeconomic impact. In this study, we investigated the frequency of genotypes (w1/w1, w $1 / \mathrm{m} 1$, or $\mathrm{m} 1 / \mathrm{m} 1)$ in the CYP1A1m1 polymorphism in a POAG patient group and a control group. We analyzed whether the CYP1Alm1 polymorphism is correlated with age, gender, ethnicity, and smoking.

\section{MATERIAL AND METHODS}

The present study was a retrospective case-control study. We collected $10 \mathrm{~mL}$ peripheral blood from 152 patients; within this group, 100 were diagnosed with primary open-angle glaucoma and 52 patients were glaucoma-free, and thus were included in the control group. Patients were treated at Pronto Eye Clinic in Goiânia - Goiás, Brazil. The study was reviewed and approved by the Pontifícia Universidade Católica de Goiás Research Ethics Committee. All patients answered a socioeconomic questionnaire and all data concerning the patients were collected in appropriate forms along with informed consent. All patients underwent complete ophthalmic examination, including a visual acuity test (testing for both corrected and uncorrected vision), gonioscopy, biomicroscopy, funduscopy, tonometry using a Goldmann applanation tonometer, Humphrey automated perimetry using the 24-2 SITA Standard test procedure, retinal angiography (optical disc), and corneal pachymetry.

The study group inclusion criteria were: $60 \%$ of optic disc excavation, intraocular pressure higher than $21 \mathrm{mmHg}$; alteration of the visual field suggesting glaucoma damage; biomicroscopy showing no infection; cataract surgery or previous eye surgery; and Shaffer gonioscopy (grade 4, which means that it would be possible to analyze all camerular gulf structures). The control group inclusion criteria were: optic disc excavation $\leq 50 \%$ and lack of asymmetry; intraocular pressure lower than $21 \mathrm{mmHg}$; normal visual field and biomicroscopy; no previous eye surgery, and no wide camerular angle (Shaffer grade 4) (Susanna, 1998; Stamper et al., 1999).

To extract genomic DNA, we used the Ilustra GFX kit (GE Healthcare; Little Chalfont, UK). The DNA samples were subjected to polymerase chain reaction to amplify the $C Y P 1 A 1$ gene. The gene $Z F X / Y$ was used as an internal control for human DNA and the nucleotide sequences used were previously described by Mota et al. (2010) and Simoni et al. (1999). All procedures used to analyze both genes were performed in duplicate.

The polymerase chain reaction-restriction fragment length polymorphism technique 
was used to detect the $C Y P 1 A 1 \mathrm{~m} 1$ polymorphism. Amplified fragments were analyzed by enzymatic digestion using the restriction enzyme MspI (Fermentas; Vilnius, Lithuania) according to manufacturer instructions. The fragments were analyzed on a $2 \%$ agarose gel and stained with ethidium bromide. The wild-type allele (w1) showed a single band of 340 base pairs (bp), the heterozygote (w1/m1) has 3 different fragments, 340, 200, and $140 \mathrm{bp}$, and the mutant homozygote $(\mathrm{ml} / \mathrm{ml})$ showed 2 fragments of 200 and $140 \mathrm{bp}$.

The chi-squared statistic test $\left(\chi^{2}\right)$ was used to compare the distribution of different genotypes from the case and control groups. The Biostat version 5.0 software was used for statistical analysis. The probability of the association between the characteristics analyzed was calculated by Fisher's test. The odds ratio (OR) and 95\% confidence interval $(95 \% \mathrm{CI})$ were calculated to evaluate the degree of association between the glaucoma and control groups. P-values lower than 0.05 were considered to be statistically significant.

\section{RESULTS}

The frequency of the alleles (w1/w1, w1/m1, and $\mathrm{m} 1 / \mathrm{m} 1)$ was assessed for the glaucoma and control groups. The frequency of genotype w1/w1 was approximately 3 -fold higher in the control group (54\%) compared to the glaucoma group (16\%) (Table 1).

\begin{tabular}{|c|c|c|c|c|c|}
\hline \multirow[t]{2}{*}{ Genotype } & \multicolumn{2}{|c|}{ Glaucoma } & \multicolumn{2}{|c|}{ Control } & \multirow[t]{2}{*}{$* \mathrm{P}$} \\
\hline & $\%$ & $\mathrm{~N}$ & $\%$ & $\mathrm{~N}$ & \\
\hline w1/w1 & 16 & 16 & 54 & 28 & \\
\hline $\mathrm{w} 1 / \mathrm{m} 1$ & 77 & 77 & 46 & 24 & 0.0001 \\
\hline $\mathrm{m} 1 / \mathrm{m} 1$ & 7 & 07 & 0 & 00 & \\
\hline Total & 100.0 & 100 & 100.0 & 52 & \\
\hline
\end{tabular}

*P is the value of $\chi^{2}$ test.

Table 2 shows the genotype distribution between males and females in the different groups. In women, the genotype $\mathrm{w} 1 / \mathrm{m} 1+\mathrm{m} 1 / \mathrm{m} 1$ was found at a 2 -fold higher frequency in the glaucoma group $(88 \%)$ than in the control group $(41 \%)(\mathrm{P}<0.0001$; OR $=0.1000,95 \% \mathrm{CI}=$ $0.0335-0.2988$ ). In men, the $\mathrm{w} 1 / \mathrm{w} 1$ genotype frequency was $2.75 \%$ higher in the control group $(44 \%)$ than in the glaucoma group $(17 \%)(\mathrm{P}=0.0259, \mathrm{OR}=0.2616,95 \% \mathrm{CI}=0.0808-0.8472)$.

Table 2. Genotype distribution between males and females within the groups studied.

\begin{tabular}{|c|c|c|c|c|c|c|c|c|}
\hline \multirow{3}{*}{$\begin{array}{l}\text { Group } \\
\text { Genotype }\end{array}$} & \multicolumn{4}{|c|}{ Female } & \multirow[t]{3}{*}{$\mathrm{P} *$} & \multirow[t]{3}{*}{ OR } & \multirow[t]{3}{*}{ Min } & \multirow[t]{3}{*}{ Max } \\
\hline & \multicolumn{2}{|c|}{ Glaucoma } & \multicolumn{2}{|c|}{ Control } & & & & \\
\hline & $\%$ & $\mathrm{~N}$ & $\%$ & $\mathrm{~N}$ & & & & \\
\hline $\mathrm{w} 1 / \mathrm{w} 1$ & 12 & 6 & 59 & 20 & & & & \\
\hline $\mathrm{w} 1 / \mathrm{m} 1+\mathrm{m} 1 / \mathrm{m} 1$ & 88 & 42 & 41 & 14 & $<0.0001$ & 0.1000 & 0.0335 & 0.2988 \\
\hline \multirow[t]{3}{*}{ Total } & 100.0 & 48 & 100.0 & 34 & & & & \\
\hline & \multicolumn{4}{|c|}{ Male } & & & & \\
\hline & \multicolumn{2}{|c|}{ Glaucoma } & \multicolumn{2}{|c|}{ Control } & & & & \\
\hline w1/w1 & 17 & 9 & 44 & 8 & & & & \\
\hline $\mathrm{w} 1 / \mathrm{m} 1+\mathrm{m} 1 / \mathrm{m} 1$ & 83 & 43 & 56 & 10 & 0.0259 & 0.2616 & 0.0808 & 0.8472 \\
\hline Total & 100.0 & 52 & 100.0 & 18 & & & & \\
\hline
\end{tabular}

*P is the value of Fisher's exact test. 
Table 3 shows the genotype distribution between smokers and non-smokers within the studied group. In the glaucoma group, 4 patients did not provide information about smoking. In smokers, the difference between the genotype of the MspI polymorphism between groups was not statistically significant $(\mathrm{P}=0.4643, \mathrm{OR}=0.0200)$. The frequency of the $\mathrm{w} 1 / \mathrm{w} 1$ genotype in non-smokers in the control group (55\%) was 3.44-fold higher than that in the glaucoma group $(16 \%)$. This result was considered to be statistically significant $(\mathrm{P}<$ $0.0001, \mathrm{OR}=0.1501,95 \% \mathrm{CI}=0.0674-0.3344)$.

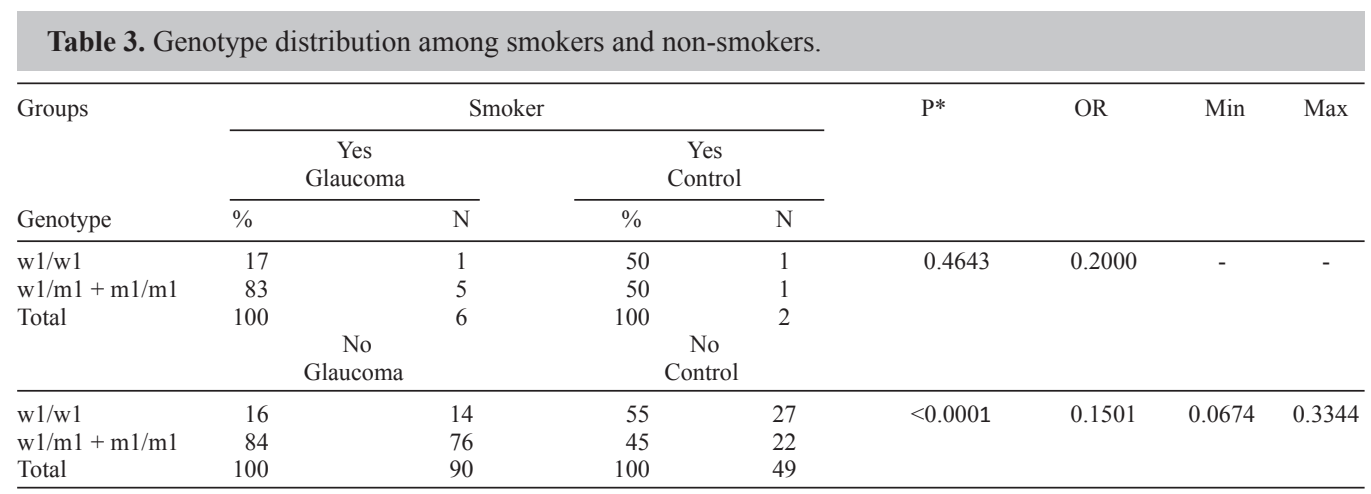

$* \mathrm{P}$ is the value of Fisher's exact test.

\section{DISCUSSION}

POAG has a complex genetic basis and can be caused by a combination of genetic risk factors and environmental factors. These factors do no act in isolation. Genes that may play an important role in the pathogenesis of POAG have been intensively investigated. Different approaches are being used to study the genetics of this type of glaucoma, offering new insights into the pathogenesis of this disease (Fingert, 2011). Recent studies examining POAG in Caucasian populations from the United States revealed that disease susceptibility was linked to the GLC1I locus on chromosome 15q (Allingham et al., 2005; Woodroffe et al., 2006). The application of this approach to late-onset POAG is the focus of current studies in this area.

Bufalo et al. (2008) noted that the CYP1A1m1 polymorphism is associated with increased susceptibility to Graves' disease, which can lead to manifestations such as ophthalmopathies. Regarding the distribution of the polymorphism CYP1A1m1, Santos (2009) found no statistically significant difference between the groups that developed and did not develop Graves' ophthalmopathy. In our study, nearly twice as many patients in the POAG group (84\%) showed the $\mathrm{m} 1$ polymorphic allele of the CYP1A1 gene. This result revealed the importance of further studies examining the CYP $1 A 1 \mathrm{~m} 1$ polymorphism and POAG.

Le et al. (2003) showed that POAG development was not related to gender, which agrees with the results of Rudnicka et al. (2006). Cedrone et al. (2008) observed a high prevalence of glaucoma in female patients, which was similar to a study conducted in Dalby, Sweden (Bengtsson, 1989). The lack of consensus regarding the results had been demonstrated earlier by Mitchell et al. (1996) in Australia and by Leske et al. (1995) in Barbados. In this study, female POAG patients showed a higher prevalence of the CYP1A1m1 polymorphism compared to the POAG male patients.

The CYP1A1 enzyme is considered to be primarily a human extra-hepatic enzyme, 
and can be induced in the lungs, lymphocytes, and placenta after exposure to polycyclic aromatic hydrocarbons, including those present in cigarette smoke (Anttila et al., 1993). The Beaver Dam Eye Study observed a minor association between smoking and POAG (Klein et al., 1993). The same result was observed by Bonovas et al. (2004), who showed that there was an increased probability that smokers and ex-smokers would develop POAG. However, Edwards et al. (2008) reported little support for the association between smoking and POAG development. Finally, Zhang et al. (2011) observed no significant association between smoking and glaucoma.

We did not observe statistically significant results for smokers in this study. In nonsmoking patients, we observed that the frequency of the CYP1A1m1 polymorphism was 1.86-fold higher in the glaucoma group than in the control group; this result was statistically significant. We did not examine whether patients were passive smokers, how often a person smokes, or whether any subjects had stopped smoking. Exposure to cigarette smoke (passive smoking) may be a considerable risk factor for POAG (Lois et al., 2008).

Our results revealed a significant difference in the presence of the CYP $1 A 1 \mathrm{~m} 1$ polymorphism between patients with POAG and the control group. The frequency of polymorphic genotypes $\mathrm{m} 1 / \mathrm{m} 1$ and $\mathrm{w} 1 / \mathrm{m} 1$ in patients from the glaucoma group was approximately 1.83 fold greater than in patients in the control group.

For gender, the frequency of female patients in the glaucoma group with the polymorphic genotypes (w1/m1 and $\mathrm{m} 1 / \mathrm{m} 1$ ) was $88 \%$ and the frequency of male patients was $83 \%$. In non-smokers, the frequency of polymorphic genotypes was approximately 1.87 -fold higher in the glaucoma group than in the control group. A statistically significant correlation was observed between the CYP1A1m1 polymorphism and POAG.

We conclude that there was a statistically significant difference in the presence of the CYP $1 A 1 \mathrm{~m} 1$ polymorphism between patients with POAG and the control group. A statistically significant correlation was observed between the $C Y P 1 A 1 \mathrm{~m} 1$ polymorphism and POAG.

\section{ACKNOWLEDGMENTS}

Research supported by Universidade Católica de Goiás, Goiânia, GO, Brazil (PUCGOIÁS/PROPE/MGene/REPLICON).

\section{REFERENCES}

Allingham RR, Wiggs JL, Hauser ER, Larocque-Abramson KR, et al. (2005). Early adult-onset POAG linked to 15q11-13 using ordered subset analysis. Invest. Ophthalmol. Vis. Sci. 46: 2002-2005.

Anttila S, Hirvonen A, Vainio H, Husgafvel-Pursiainen K, et al. (1993). Immunohistochemical localization of glutathione S-transferases in human lung. Cancer Res. 53: 5643-5648.

Barbosa AM, Frare AB, Costa NB, Silva RE, et al. (2012). GSTM1 polymorphism in patients with primary open-angle glaucoma. Genet. Mol. Res. 11: 3256-3262.

Bengtsson BO (1989). Incidence of manifest glaucoma. Br. J. Ophthalmol. 73: 483-487.

Bonovas S, Filioussi K, Tsantes A and Peponis V (2004). Epidemiological association between cigarette smoking and primary open-angle glaucoma: a meta-analysis. Public Health 118: 256-261.

Bufalo NE, Santos RB, Cury AN, Andrade RA, et al. (2008). Genetic polymorphisms associated with cigarette smoking and the risk of Graves' disease. Clin. Endocrinol. 68: 982-987.

Cedrone C, Mancino R, Cerulli A, Cesareo M, et al. (2008). Epidemiology of primary glaucoma: prevalence, incidence, and blinding effects. Prog. Brain Res. 173: 3-14.

Corchero J, Pimprale S, Kimura S and Gonzalez FJ (2001). Organization of the CYP1A cluster on human chromosome 15: implications for gene regulation. Pharmacogenetics 11: 1-6. 
Edwards R, Thornton J, Ajit R, Harrison RA, et al. (2008). Cigarette smoking and primary open angle glaucoma: a systematic review. J. Glaucoma. 17: 558-566.

Fingert JH (2011). Primary open-angle glaucoma genes. Eye 25: 587-595.

Franco YO and Franco LM (2003). Biotransformação: importância e toxicidade. Saúde Rev. 5: 69-76.

Johnson AT, Richards JE, Boehnke M, Stringham HM, et al. (1996). Clinical phenotype of juvenile-onset primary openangle glaucoma linked to chromosome 1q. Ophthalmology 103: 808-814.

Klein BE, Klein R and Ritter LL (1993). Relationship of drinking alcohol and smoking to prevalence of open-angle glaucoma. The Beaver Dam Eye Study. Ophthalmology 100: 1609-1613.

Le A, Mukesh BN, McCarty CA and Taylor HR (2003). Risk factors associated with the incidence of open-angle glaucoma: the visual impairment project. Invest. Ophthalmol. Vis. Sci. 44: 3783-3789.

Leske MC, Connell AM, Wu SY, Hyman LG, et al. (1995). Risk factors for open-angle glaucoma. The Barbados Eye Study. Arch. Ophthalmol. 113: 918-924.

Lin HJ, Chen WC, Tsai FJ and Tsai SW (2002). Distributions of p53 codon 72 polymorphism in primary open angle glaucoma. Br. J. Ophthalmol. 86: 767-770.

Lois N, Abdelkader E, Reglitz K, Garden C, et al. (2008). Environmental tobacco smoke exposure and eye disease. $B r . J$. Ophthalmol. 92: 1304-1310.

Mahdy MA (2010). Gene therapy in glaucoma-part 2: Genetic etiology and gene mapping. Oman. J. Ophthalmol. 3: 51-59.

Mitchell P, Smith W, Attebo K and Healey PR (1996). Prevalence of open-angle glaucoma in Australia. The Blue Mountains Eye Study. Ophthalmology 103: 1661-1669.

Monemi S, Spaeth G, DaSilva A, Popinchalk S, et al. (2005). Identification of a novel adult-onset primary open-angle glaucoma (POAG) gene on 5q22.1. Hum. Mol. Genet. 14: 725-733.

Mota P, Moura DS, Vale AG, Coimbra H, et al. (2010). Polimorfismos dos alelos $\mathrm{m} 1$ e $\mathrm{m} 2$ do gene CYP1A1: Susceptibilidade genética para o cancro do pulmão. Rev. Port. Pneumol. 16: 89-98.

Quigley HA and Vitale S (1997). Models of open-angle glaucoma prevalence and incidence in the United States. Invest. Ophthalmol. Vis. Sci. 38: 83-91.

Quigley HA, Nickells RW, Kerrigan LA, Pease ME, et al. (1995). Retinal ganglion cell death in experimental glaucoma and after axotomy occurs by apoptosis. Invest. Ophthalmol. Vis. Sci. 36: 774-786.

Rezaie T, Child A, Hitchings R, Brice G, et al. (2002). Adult-onset primary open-angle glaucoma caused by mutations in optineurin. Science 295: 1077-1079.

Rossit A and Conforti-Froes NDT (2000). Suscetibilidade genética, biometabolismo e câncer. Rev. Soc. Bras. Cancerol. 3: 26-30.

Rudnicka AR, Mt-Isa S, Owen CG, Cook DG, et al. (2006). Variations in primary open-angle glaucoma prevalence by age, gender, and race: a Bayesian meta-analysis. Invest. Ophthalmol. Vis. Sci. 47: 4254-4261.

Santos RB (2009). Perfil Genético de Risco para Doença de Graves e para a Oftalmopatia de Graves em uma População Brasileira. Doctoral thesis - Universidade Estadual de Campinas, Campinas, 84.

Silva CTX (2012). Análise do Polimorfismo da Glutationa S-transferase T1 E M1 em Pacientes Portadores de Glaucoma Primário de Ângulo Aberto. Master's thesis - Pontifícia Universidade Católica de Goiás, Goiânia.

Silva RE, Arruda JT, Rodrigues FW and Moura KK (2009). Primary open angle glaucoma was not found to be associated with p53 codon 72 polymorphism in a Brazilian cohort. Genet. Mol. Res. 8: 268-272.

Simoni M, Bakker E, Eurlings MC, Matthijs G, et al. (1999). Laboratory guidelines for molecular diagnosis of Y-chromosomal microdeletions. Int. J. Androl. 22: 292-299.

Slattery ML, Samowtiz W, Ma K, Murtaugh M, et al. (2004). CYP1A1, cigarette smoking, and colon and rectal cancer. Am. J. Epidemiol. 160: 842-852.

Stamper LR, Lieberman MF and Drake MV (1999). Diagnosis and Therapy of the Glaucomas. 7th edn. Mosby: Elsevier Health Sciences, New York.

Stewart WC, Kolker AE, Sharpe ED, Day DG, et al. (2000). Factors associated with long-term progression or stability in primary open-angle glaucoma. Am. J. Ophthalmol. 130: 274-279.

Stoilov I, Akarsu AN and Sarfarazi M (1997). Identification of three different truncating mutations in cytochrome P4501B1 (CYP1B1) as the principal cause of primary congenital glaucoma (Buphthalmos) in families linked to the GLC3A locus on chromosome 2p21. Hum. Mol. Genet. 6: 641-647.

Stone EM, Fingert JH, Alward WL, Nguyen TD, et al. (1997). Identification of a gene that causes primary open angle glaucoma. Science 275: 668-670.

Susanna Jr R (1998). Glaucoma. Manual de Orientação. Conselho Brasileiro de Oftalmologia, São Paulo.

Tielsch JM, Katz J, Sommer A, Quigley HA, et al. (1994). Family history and risk of primary open angle glaucoma. The Baltimore Eye Survey. Arch. Ophthalmol. 112: 69-73.

Woodroffe A, Krafchak CM, Fuse N, Lichter PR, et al. (2006). Ordered subset analysis supports a glaucoma locus at 
GLC1I on chromosome 15 in families with earlier adult age at diagnosis. Exp. Eye Res. 82: 1068-1074.

Zhang X, Kahende J, Fan AZ, Barker L, et al. (2011). Smoking and visual impairment among older adults with age-related eye diseases. Prev. Chronic. Dis. 8: A84. 